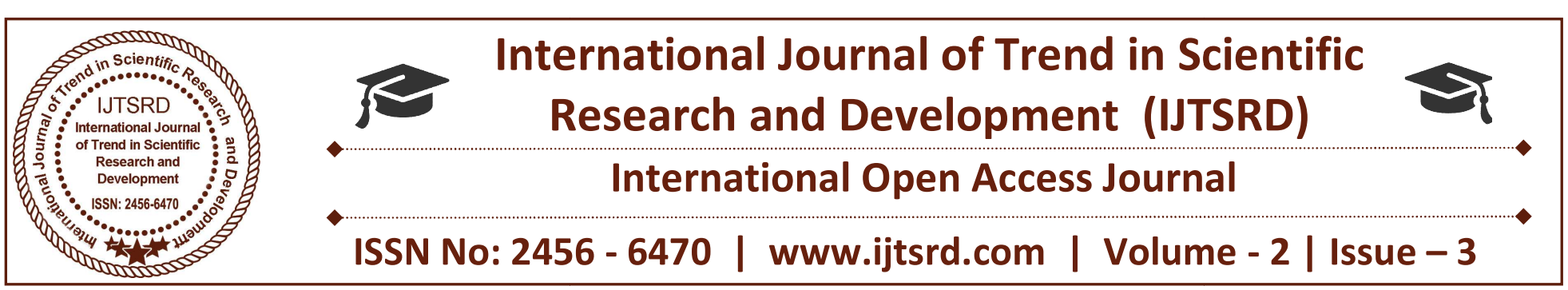

\title{
Development and application of Liquid Chromatographic method for determination of Caspofungin Acetate in sterile, lyophilized powder for Injection
}

\author{
Dr. L. Satyanarayana, Dr. Sumalatha Reddi \\ Department of Pharmaceutical Analysis, \\ Omega College of Pharmacy, Ghatkesar, Hyderabad, Telangana, India
}

\begin{abstract}
Caspofungin is an antifungal agent of the novel echinocandin class. Caspofungin, the first inhibitor of fungal $b-1,3$ glucan synthesis to receive approval by the United States Food and Drug Administration, is effective for the treatment of mucosal and invasive candidiasis and invasive aspergillosis. It is also active in vitro and in animal models against a number of other filamentous and dimorphic endemic fungi and in animal models of Pneumocystis carinii infection.
\end{abstract} Caspofungin is a water-soluble amphipathic lipopeptide is a semisynthetic derivative of pneumocandin B0, a fermentation product of Glarea lozoyensis. Developing a accurate and precise alytical method for the estimation of cagpsofungin in a sterile, lyophilized product for intravenous (IV) infusion a is very challenging, due to the formation of drug-drug and drug-excipient interactions. The present study demonstrates the applicability of chromatographic method to develop a new, sensitive, single HPLC method for the quantitative determination of antifungal agents in freeze dried powder for injection pharmaceutical dosage form. Chromatographic separation active pharmaceutical ingredient was achieved by using a isocratic elution at a flow rate of $1.0 \mathrm{~mL} / \mathrm{min}$ on X-Terra RP-18 column $(250 \mathrm{~mm} \times 4.6$ $\mathrm{mm}, 5 \mu \mathrm{m}$ particle size, $100 \AA$ pore size) at ambient temperature. The contents of the mobile phase were 3.48 gms of Di Potassium hydrogen ortho-phosphate $(0.03 \mathrm{M})$ in $1000 \mathrm{ml}$ of water and by adjusting the $\mathrm{pH}$ to 3.2 with dilute ortho-phosphoric acid (mobile phase solvent-A) and acetonitrile (mobile phase solvent-B) in a isocratic mode in the ratio of 30: $70(\mathrm{v} / \mathrm{v})$ of separation was used to resolute the Caspofungin. UV detection at $278 \mathrm{~nm}$ was employed to monitor the

analytes. A linear response was observed for caspofungin over the concentration range $0.5-6 \mu \mathrm{g}$ / $\mathrm{mL}$. Limit of detection (LOD) and Limit of quantification (LOQ) for Capsofungin were found to be $0.001 \mu \mathrm{g} / \mathrm{mL}$, and $0.003 \mu \mathrm{g} / \mathrm{mL}$ respectively.

Keywords: Caspofungin, Isocratic-HPLC, Casporan $\mathbb{\circledR}$, Lyophilized powder for injection

\section{Introduction:}

Casporan ${ }^{\circledR}$ is a sterile, lyophilized product for intravenous (IV) infusion that contains a semisynthetic lipopeptide (echinocandin) compound synthesized from a fermentation product of Glarea lozoyensis ${ }^{1-3}$. Casporan $\AA$ is the first of a new class of antifungal drugs (echinocandins) that inhibit the synthesis of $\beta(1,3)$-D-glucan, an integral component of the fungal cell wall. ${ }^{4}$ Caspofungin acetate, the active ingredient of Casporan $\AA$, inhibits the synthesis of $\beta(1,3)$-D-glucan, an essential component of the cell wall of susceptible Aspergillus species and Candida species. $\beta(1,3)$-D-glucan is not present in mammalian cells ${ }^{5}$. Caspofungin has shown activity against Candida species and in regions of active cell growth of the hyphae of Aspergillus fumigates ${ }^{6-8}$. It is indicated for the treatment of invasive Aspergillus infections in patients who are refractory or intolerant of other therapies; treatment of candidemia and other Candida infections (intra-abdominal abscesses, peritonitis, pleural space); treatment of esophageal candidiasis; empirical treatment for presumed fungal infections in febrile neutropenic patients Casporan $(\AA$ (caspofungin acetate) is $1-[(4 \mathrm{R}, 5 \mathrm{~S})-5-[(2-$ aminoethyl)amino]-N2 -(10,12-dimethyl-1- 
oxotetradecyl)-4-hydroxy-L-ornithine]-5-[(3R)-3hydroxy-L-ornithine] pneumocandin B0 diacetate (salt). Casporan ${ }^{\circledR} \quad 50 \mathrm{mg}$ also contains: $39 \mathrm{mg}$ sucrose, $26 \mathrm{mg}$ mannitol, glacial acetic acid, and sodium hydroxide. Casporan ${ }^{\circledR} 70 \mathrm{mg}$ also contains 54 mg sucrose, $36 \mathrm{mg}$ mannitol, glacial acetic acid, and sodium hydroxide. Caspofungin acetate is a hygroscopic, white to off-white powder. It is freely soluble in water and methanol, and slightly soluble in ethanol. The $\mathrm{pH}$ of a saturated aqueous solution of caspofungin acetate is approximately 6.6. The empirical formula is $\mathrm{C}_{52} \mathrm{H}_{88} \mathrm{~N}_{10} \mathrm{O}_{15} \cdot 2 \mathrm{C}_{2} \mathrm{H}_{4} \mathrm{O}_{2}$ and the formula weight is $1213.42^{9-10}$. Casporan $\AA 50 \mathrm{mg}$ is a white to off-white powder/cake for infusion in a vial with a red aluminum band and a plastic cap supplied as one single-use vial. Casporan ${ }^{\circledR} 70 \mathrm{mg}$ is a white to off-white powder/cake for infusion in a vial with a yellow/orange aluminum band and a plastic cap.

Figure-1: Chemical structures of Caspofungin

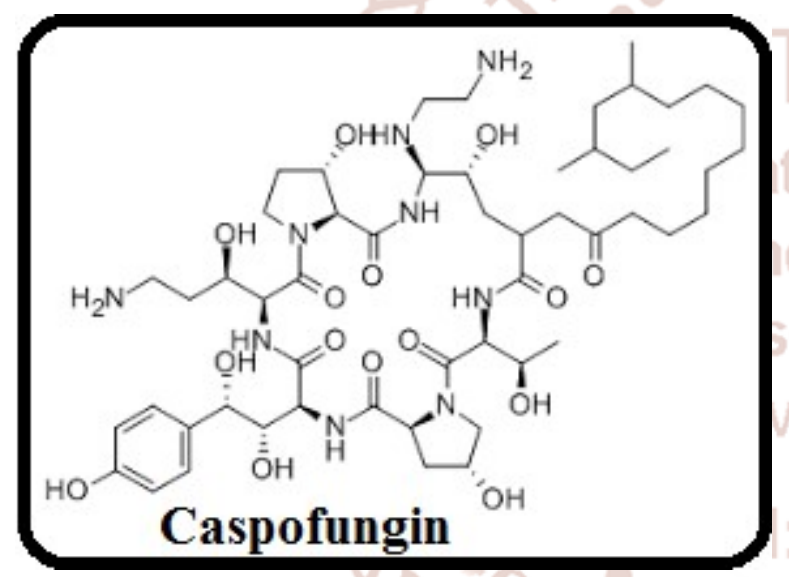

A survey of literature has revealed only one analytical method for the determination of caspofungin in biological fluids. These include; high-performance liquid chromatography (HPLC) ${ }^{11}$. On the contrary, to the best of our knowledge, there is no method reporting the determination of Caspofungin in pharmaceutical formulation. In this paper, we report the simple precise and accurate RP-HPLC method for the assay of caspofungin acetate for Intravenous (IV) Infusion in sterile lyophilized powder for injection dosage form. The new method is capable of separating active ingredient present in the Intravenous (IV) Infusion. Validation of the current method will be performed according to the requirements of USP for assay determination which include accuracy, precision, selectivity, linearity and range.

\section{Experimental:}

Chemicals and reagents: Caspofungin was obtained as kind gift sample from Gland Pharma Ltd, Hyderabad. Potassium dihydrogen ortho-phosphate, methanol, acetonitrile and ortho-phosphoric acid were obtained from Merck, Mumbai, India. All the solutions were prepared in Milli Q water (Millipore, USA). Test samples composed of Casporan ${ }^{\circledR} 50 \mathrm{mg}$ lyophilized powder for intravenous administration vial, Ranbaxy, India contains $50 \mathrm{mg}$ of Caspofungin, is obtained from local market.

HPLC Instrumentation and Chromatographic conditions: Quantitative HPLC was performed on the Waters Alliance 2695 Separations Module is a high performance liquid chromatographic system with a quaternary, low-pressure mixing pump and inline vacuum degassing. Waters Alliance 2695 separation module (Waters Corporation, Milford, USA) equipped with $2489 \mathrm{UV} /$ visible detector or 2998 PDA detector with Empower 2 software was used for the analysis. Flow rates from $50 \mathrm{uL} / \mathrm{min}$ to $5 \mathrm{~mL} / \mathrm{min}$ can be generated for use with $2.1 \mathrm{~mm}$ ID columns and larger. The auto-sampler has a maximum capacity of 120 vials $(12 \times 32,2-\mathrm{mL})$ with programmable temperature control from 4 to $40^{\circ} \mathrm{C}$. A heated column compartment provides temperatures from 5 degrees above ambient to $65^{\circ} \mathrm{C}$. The detector is a photodiode array (model 2996) with a wavelength range of 190$800 \mathrm{~nm}$ and sensitivity settings from 0.0001-2.0000 absorbance units The HPLC system was equipped with a column compartment with temperature control and an on-line degasser. X-Terra RP-C18 Column (250x4.6 mm i.d; particle size $5 \mu \mathrm{m}$ ) was used for separation of Caspofungin. The contents of the mobile phase were 3.48 gms of $\mathrm{Di}$ Potassium hydrogen ortho-phosphate $(0.03 \mathrm{M})$ in $1000 \mathrm{ml}$ of water and by adjusting the $\mathrm{pH}$ to 3.2 with dilute ortho-phosphoric acid (mobile phase solvent-A) and acetonitrile (mobile phase solvent-B) in a isocratic mode in the ratio of 30: $70(\mathrm{v} / \mathrm{v})$ of separation was used to resolute the Caspofungin. They were filtered before use through a $0.45 \mu \mathrm{m}$ membrane filter and degassed by sonication. The flow was adjusted at 1.0 $\mathrm{ml} / \mathrm{min}$ flow rate and $20 \mu \mathrm{L}$ injection load volumes were maintained. The eluted compounds were monitored at $278 \mathrm{~nm}$. The column oven temperature was maintained at $25 \circ \mathrm{C}$. Data acquisition, analysis, and reporting were performed by Empower2 (Waters) chromatography software. 


\section{Preparation of Solutions:}

Standard and stock solutions: Standard solution of the active pharmaceutical ingredient was prepared in the following manner: Transfer $5 \mathrm{mg}$ of caspofungin working standard into a $100 \mathrm{ml}$ volumetric flask, dissolve and dilute with Acetonitrile and water in the ratio of $50: 50 \mathrm{v} / \mathrm{v}$ as diluent. $5 \mathrm{ml}$ of the resulting solution is further diluted up to $50 \mathrm{ml}$ in volumetric flask with diluents. The resulting solution contains 5 $\mu \mathrm{g} / \mathrm{mL}$ of caspofungin as working standard solutions. The prepared stock solutions were stored at $4{ }^{0} \mathrm{C}$ and protected from light.

Preparation of the Sample solution: Casporan ${ }^{\circledR} 50$ $\mathrm{mg}$ is a white to off-white powder/cake for infusion in a vial with a red aluminum band and a plastic cap. Casporan ${ }^{\circledR}$ is a sterile, lyophilized product for intravenous (IV) infusion that contains a semisynthetic lipopeptide (echinocandin) compound synthesized from a fermentation product of Glarea lozoyensis. Casporan ${ }^{\circledR} 50 \mathrm{mg}$ also contains: $39 \mathrm{mg}$ sucrose, $26 \mathrm{mg}$ mannitol, glacial acetic acid, and sodium hydroxide. The contents of 5 vials are emptied and their average weight was calculated. The vial contents were blended to a homogeneous powder and a quantity equivalent to $5 \mathrm{mg}$ was weighed and transferred in to a $100-\mathrm{mL}$ volumetric flask, extracted in diluent by sonication, and filtered through Whatman no. 41 filter paper. The filtrate $(5 \mathrm{~mL})$ was quantitatively transferred to a $50-\mathrm{mL}$ volumetric flask, and solution was diluted to volume with the diluents. The resulting solution contains $5 \mu \mathrm{g} / \mathrm{mL}$ of caspofungin as working sample solutions. The prepared stock solutions were stored at $4{ }^{\circ} \mathrm{C}$ and protected from light.

\section{Solutions for validation study:}

Calibration and Quality control samples: Calibration standards $(0.5-6 \mu \mathrm{g} / \mathrm{mL}$ of caspofungin were prepared from working standard solutions by appropriate dilution with Acetonitrile and water in the ratio of 50:50 v/v as diluents. Quality control (QC) samples for accuracy studies were prepared at three concentrations of the linearity range $(4 \mu \mathrm{g} / \mathrm{mL}, 5 \mu \mathrm{g} /$ $\mathrm{mL}$ and $6 \mu \mathrm{g} / \mathrm{mL}$ ) for caspofungin were prepared from the standard solutions.

Method Validation: The developed chromatographic method was validated for selectivity, linearity, precision, accuracy, sensitivity, robustness and system suitability.
Specificity: The terms selectivity and specificity are often used interchangeably. The specificity of the developed LC method for quantification of active pharmaceutical ingredient was determined the presence of excipients present in pharmaceutical products. In specificity study, interference between drugs and excipients usually employed in lyophilized powder for injection was evaluated from the comparison of spectral purity obtained from the analysis for the standard solutions and sample solutions.

System suitability: The system suitability was assessed by six replicate analyses of the drugs at concentrations of $5 \mu \mathrm{g} / \mathrm{mL}$ for caspofungin. The acceptance criterion was $\pm 2 \%$ for the RSD for the peak area and retention times for all four analytes. The system suitability parameters with respect to theoretical plates, tailing factor, repeatability and resolution between peak and peaks of the other three analytes were defined.

Linearity: Linearity of the method was evaluated at seven equi-spaced concentration levels by diluting the standard solutions to give solutions over the ranges $10-120 \%$ target concentration for main analyte of interest. The calibration curves were constructed at seven concentrations between $0.5-6 \mu \mathrm{g} / \mathrm{mL}$ for caspofungin. These were injected in triplicate and the peak areas were inputted into a Microsoft Excel ${ }^{\circledR}$ spreadsheet program to plot calibration curves. The linearity was evaluated by linear regression analysis, which was calculated by the least square regression method. The peak areas of the analyte to concentration of analyte were used for plotting the linearity graph. The linearity data is reported in Table3.

\section{Table-3: Linearity Data for caspofungin}

Precision: Precision was evaluated in terms of intraday repeatability and inter-day reproducibility. The intra-day repeatability was investigated using six separate sample solutions prepared, as reported above, from the freshly reconstructed tablet formulations at $100 \%$ of the target level. Each solution was injected in triplicate and the peak areas obtained were used to calculate means and RSD\% values. The inter-day reproducibility was, by preparing and analyzing in triplicate sample solutions from the reconstructed formulations at the same concentration level of intra- 
day repeatability; the means and RSD\% values were calculated from peak areas. (Table-4)

Table-4: Intra-day and inter-day precision data for for caspofungin

Accuracy: The accuracy of the method was determined by measuring the recovery of the drug by the method of standard additions. Quality control (QC) samples for accuracy studies were prepared at three concentrations of the linearity range $(4 \mu \mathrm{g} / \mathrm{mL}$ (80\% dilution), $5 \mu \mathrm{g} / \mathrm{mL}$ (100\% dilution) and $6 \mu \mathrm{g} /$ $\mathrm{mL}(120 \%$ dilution) for caspofungin were prepared from the standard solutions. Known amounts of $10 \%$ dilution of each drug corresponding to $80 \%, 100 \%$, and $120 \%$ of the target test concentrations $(0.5 \mu \mathrm{g} / \mathrm{mL}$ of caspofungin) were added to a placebo mixture to determine whether the excipients present in the formulation led to positive or negative interferences. Each set of additions was repeated three times at each level. Extraction sample preparation procedure is followed and assayed against qualified reference standard. The accuracy was expressed as the percentage of the analytes re-covered by the assay. (Table-5)

Table-5: Accuracy: recovery data for caspofungin

Sensitivity: Limits of detection (LOD) and quantification (LOQ) were estimated from the signalto-noise ratio. The detection limit was determined as the lowest concentration level resulting in a peak area of three times the baseline noise. The limit of detection was determined, by injecting progressively low concentrations of analyte of interest. The quantification limit was determined as the lowest concentration level that provided a peak area with signal-to-noise 10.

Robustness: To determine the robustness of the developed method, experimental conditions were deliberately changed and the relative standard deviation for replicate injections of caspofungin and the USP resolution factor between and the other two peaks were evaluated. The mobile phase flow rate was $1.0 \mathrm{~mL} / \mathrm{min}$. This was changed by \pm 0.2 units to 0.8 and $1.2 \mathrm{~mL} / \mathrm{min}$. The effect of stationary phase was studied by the use of LC columns from different batches at $25^{\circ} \mathrm{C}$. The effect of buffer $\mathrm{pH}$ was studied at $\mathrm{pH} 3.0$ and 3.4 ( \pm 0.2 units). The chromatographic variations were evaluated for resolution between and the other three analytes in a system suitability solution with respect to retention time RT and \% assay of drugs.
Table-6: Robustness data for caspofungin

Solution stability: To assess the solution stability, standard and test solutions were kept at $25{ }^{\circ} \mathrm{C}$ (laboratory temperature) for $24 \mathrm{~h}$. These solutions were compared with freshly prepared standard and test solutions.

\section{RESULTS AND DISCUSSION:}

HPLC method development: The API solution of analyte of interest i,e., caspofugin was prepared in diluent at a concentration of $50 \mu \mathrm{g} / \mathrm{mL}$ and scanned in UV-Visible spectrometer; and the caspofungin was found to have UV maxima at around $278 \mathrm{~nm}$. Hence detection at $278 \mathrm{~nm}$ was selected for method development purpose. Some important parameters, $\mathrm{pH}$ of the mobile phase, concentration of the acid or buffer solution, percentage and type of the organic modifier, etc. were tested for a good chromatographic separation. The main analytical challenge during development of a new method was obtaining adequate retention of the polar compound caspofungin. Trials showed that acidic mobile phase with reverse phase column gives symmetric and sharp peaks. For this reason, potassium dihydrogen phosphate buffer with pH-3.2 was adjusted with o-phosphoric acid was preferred as acidic buffer solution. Acetonitrile and buffer $n$ the ratio of 70:30 (v/v) was chosen as the organic modifier because it dissolves drugs very well. Mobile phase composition in isocratic mode at a flow rate of $1.0 \mathrm{~mL}$ per minute was observed for a good resolution. Then method was optimized to separate the active ingredient by changing to isocratic mode. The satisfactory chromatographic separation, with good peak shapes were achieved on X-Terra RP-18C18 $(250 \times 4.6) \mathrm{mm}$ with $5 \mu \mathrm{m}$ particles, using the column temperature as maintained at $35^{\circ} \mathrm{C}$ and the detection was monitored at a wavelength of $278 \mathrm{~nm}$. The injection volume was $20 \mu \mathrm{L}$. Acetonitrile and water in the ratio of 50:50 v/v) were used as diluent. In the optimized isocratic conditions, caspofungin was well separated with a resolution (Rs) of greater than 2 and the typical retention time of about 3.35 minutes, the typical chromatogram of System suitability shown in Figure 2.

\section{Method validation:}

The developed method was validated, as described below, for the following parameters: system suitability, selectivity, linearity, precision, accuracy and $\mathrm{LOD} / \mathrm{LOQ}$. 
Selectivity: Selectivity of the current method was demonstrated by good separation of the active ingredients. Furthermore, matrix components, e.g. excipients, do not interfere with the four analytes as they have no absorbance. The representative chromatogram (Fig. 5) of the fixed dosage form solution containing excipients showed no peak interfering with analytes; moreover the adjacent chromatographic peaks were separated with resolution factors $>3$. Overall, these data demonstrated that the excipients did not interfere with the active ingredients peaks, indicating selectivity of the method

System suitability: The RSD values of peak area and retention time for the analytes are within $2 \%$ indicating the suitability of the system.

Figure-2: System suitability chromatogram of working standard solution contains $5 \mu \mathrm{g} / \mathrm{mL}$ of Caspofungin.

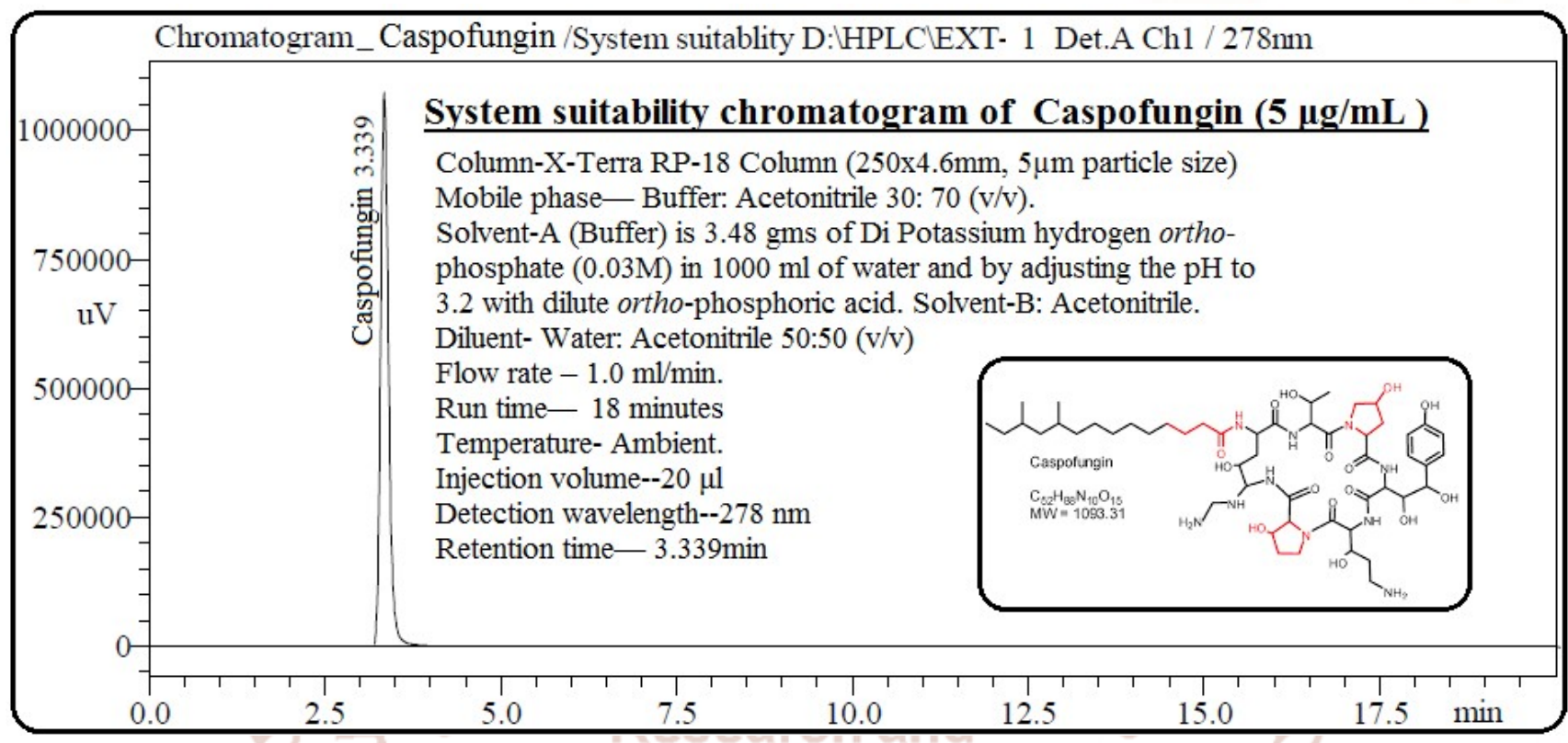

Table-2: Results of System suitability study.

\begin{tabular}{|l|l|}
\hline \multicolumn{1}{|c|}{ Parameter } & \multicolumn{1}{c|}{ Caspofungin } \\
\hline Retention time & 3.34 minutes \\
\hline Theoretical plates & 8355.229 \\
\hline Tailing Factor & 1.281 \\
\hline HETP & $2.99214 \times 10^{-5}$ \\
\hline USP plates/meter & 33420.916 \\
\hline Resolution & 3.544 \\
\hline Peak area & 8492820 \\
\hline \% of Peak area & 99.98 \\
\hline
\end{tabular}

Linearity and range: Seven concentration levels within $10-120 \%$ of the target concentration range for analytes were considered to study the linearity. The calibration curves were prepared by plotting the peak area of the drug to the respective concentrations, which were linear in the range of $0.5-6 \mu \mathrm{g} / \mathrm{mL}$ for Caspofungin. Peak areas of the active ingredients and concentrations were subjected to least square linear regression analysis to calculate the calibration equations and correlation coefficients. The mean regression equations were found as $\mathrm{y}=1651731.671 \mathrm{x}+$ 296419.5807 for caspofungin. The square of the correlation coefficient $(\mathrm{r} 2>0.999)$ demonstrated a significant correlation between the concentration of analytes and detector response. The results show that there is an excellent correlation between the peak area ratios and the concentrations of drugs in the range tested. 
International Journal of Trend in Scientific Research and Development (IJTSRD) ISSN: 2456-6470

Table-3: Linearity data for the Casparan ${ }^{\circledR}$ - lyophilized product for intravenous (IV) infusion.

\begin{tabular}{|l|l|l|l|}
\hline Concentration & Peak Area & Parameter & Caspofungin \\
\hline $0.5 \mu \mathrm{g} / \mathrm{mL}$ & 915070 & Concentration Range & $0.5-6 \mu \mathrm{g} / \mathrm{mL}$ \\
\hline $1 \mu \mathrm{g} / \mathrm{mL}$ & 2098372 & Regression equation & $\mathrm{y}=1651731.671 \mathrm{x}+296419.5807$ \\
\hline $2 \mu \mathrm{g} / \mathrm{mL}$ & 3669520 & Correlation Coefficient & 0.999 \\
\hline $3 \mu \mathrm{g} / \mathrm{mL}$ & 5230975 & 0.95 Confidence interval & Lower-Limit-0.993/ Upper Limit-1 \\
\hline $4 \mu \mathrm{g} / \mathrm{mL}$ & 7018803 & 0.95 Confidence interval & Lower-Limit-0.987/ Upper Limit-1 \\
\hline $5 \mu \mathrm{g} / \mathrm{mL}$ & 8496198 & Limit of Detection(LOD) & $0.001 \mu \mathrm{g} / \mathrm{mL}$ \\
\hline $6 \mu \mathrm{g} / \mathrm{mL}$ & 10158295 & Limit of Quantification(LOQ) & $0.003 \mu \mathrm{g} / \mathrm{mL}$ \\
\hline
\end{tabular}

Figure-3: Calibration Curve of Casparan®-lyophilized product for intravenous (IV) infusion.

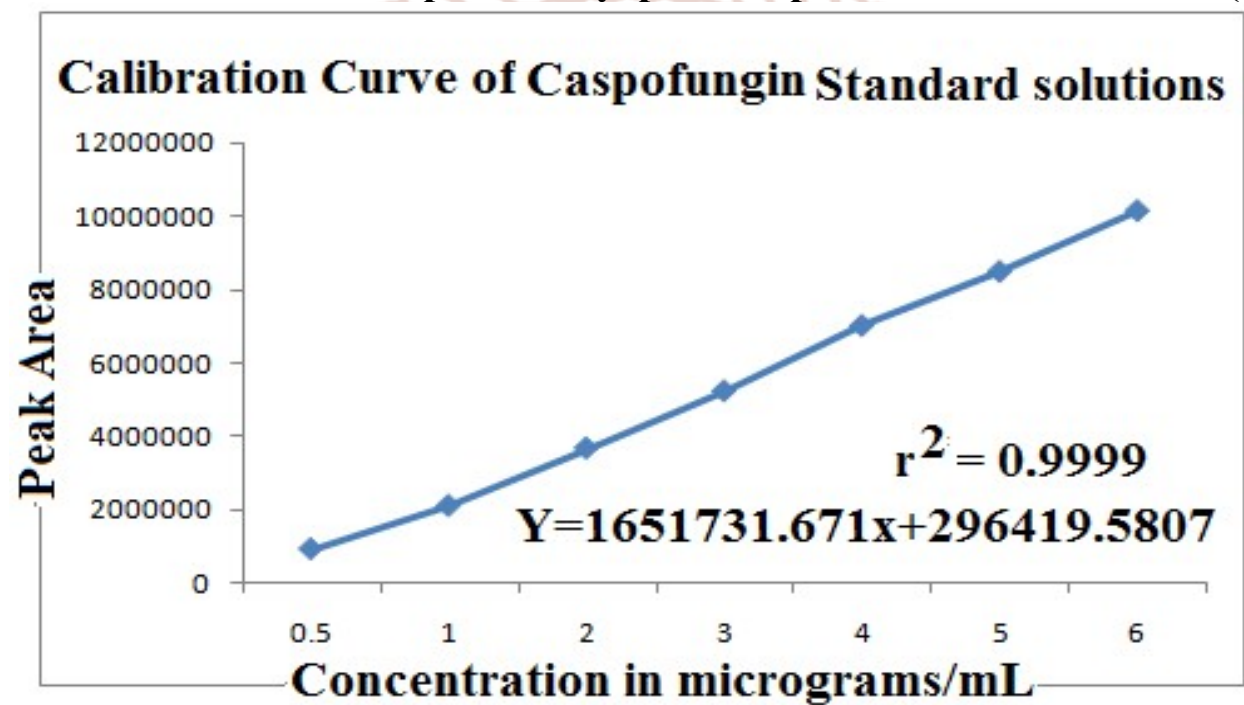

Precision: Precision of this method was determined by injecting the standard solution of the three analytes six times. The R.S.D. of peak area of six replicates was found to be less than 2. The results obtained are shown in Table 4 . In all instances the $\%$ RSD values were less than $2 \%$.

Table-4: Intra-day and inter-day precision data for Caspofungin

\begin{tabular}{|l|l|l|l|l|}
\hline Precision data of Caspofungin & \multicolumn{2}{|l|}{ Inter-day precision } & \multicolumn{2}{l|}{ Intra-day precision } \\
\hline Analyte-conc. $(5 \mu \mathrm{g} / \mathrm{ml})$ & $\begin{array}{l}\text { Retention } \\
\text { time in min. }\end{array}$ & Peak Area & $\begin{array}{l}\text { Retention } \\
\text { time in min. }\end{array}$ & Peak Area \\
\hline Caspofungin injection-1 & 3.159 & 8478697 & 3.374 & 8483622 \\
\hline Caspofungin injection-2 & 3.260 & 8505817 & 3.270 & 8609071 \\
\hline Caspofungin injection-3 & 3.167 & 8454375 & 3.191 & 8496105 \\
\hline Caspofungin injection-4 & 3.302 & 8470229 & 3.163 & 8449765 \\
\hline Caspofungin injection-5 & 3.163 & 8483608 & 3.162 & 8454135 \\
\hline Caspofungin injection-6 & 3.140 & 8402989 & 3.288 & 8462189 \\
\hline Mean & 3.199 & 8465952 & 3.241 & 8492481 \\
\hline \% RSD. & 2.058 & 0.415 & 2.595 & 0.704 \\
\hline Std. Devitio & 0.066 & 35157 & 0.084 & 59829 \\
\hline
\end{tabular}


Accuracy: Percentage recovery of the active ingredient using this method was determined using Casporan ${ }^{\circledR} 50$ $\mathrm{mg}$ is a white to off-white powder/cake for infusion in a vial with a red aluminum band and a plastic cap. Casporan ${ }^{\circledR}$ is a sterile, lyophilized product for intravenous (IV) infusion that contains a semisynthetic lipopeptide (echinocandin) compound. The results of accuracy studies from standard solution and excipient matrix were shown in Table 5; recovery values demonstrated that the method was accurate within the desired range.

\section{Table-5: Accuracy study and recovery data for Caspofungin}

\begin{tabular}{|c|c|c|c|c|c|c|}
\hline \multirow[t]{2}{*}{ S. No } & \multicolumn{2}{|c|}{$\begin{array}{l}\text { Recovery at } 80 \% \\
\text { dilution Level Peak areas }\end{array}$} & \multicolumn{2}{|c|}{$\begin{array}{l}\text { Recovery at } 100 \% \\
\text { dilution Level Peak areas }\end{array}$} & \multicolumn{2}{|c|}{$\begin{array}{l}\text { Recovery at } 120 \% \\
\text { dilution Level Peak areas }\end{array}$} \\
\hline & Standard & Spiked & Standard & Spiked & Standard & Spiked \\
\hline 1 & 6842022 & 7741718 & 8436297 & 9293221 & 10217467 & 11310318 \\
\hline 2 & 6978144 & 7774423 & 8438538 & 9349224 & 10116313 & 11347869 \\
\hline 3 & 6864145 & 7763034 & 8434851 & 9388266 & 10348643 & 11351774 \\
\hline Avg & 6894770.333 & 7759725.0 & 8436562 & 9343570.3 & 10227474.33 & 11336654 \\
\hline Std.Dev & 73046.10 & 16601.70 & 1857.73 & 47774.06 & 116487.84 & 22890.78 \\
\hline$\% \mathrm{RSD}$ & & & 0.022 & 0.511 & 1.139 & 0.202 \\
\hline \% Recovery & 98.90 & lnte & 98.28 & 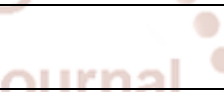 & 106.36 & \\
\hline \multicolumn{7}{|c|}{$\begin{array}{l}\text { Casparan }{ }^{\circledR} \text { sterile, lyophilized product for intravenous (IV) infusion working sample solution } \\
\text {-at } 80 \% \text { level }(4 \mu \mathrm{g} / \mathrm{ml} \text { was spiked with } 10 \% \text { of mixed standard solution of API's }(0.5 \mu \mathrm{g} / \mathrm{ml}) \\
\text {-at } 100 \% \text { level }(5 \mu \mathrm{g} / \mathrm{ml} \text { was spiked with } 10 \% \text { of mixed standard solution of API's }(0.5 \mu \mathrm{g} / \mathrm{ml}) \\
\text {-at } 120 \% \text { level }(6 \mu \mathrm{g} / \mathrm{ml} \text { was spiked with } 10 \% \text { of mixed standard solution of API's }(0.5 \mu \mathrm{g} / \mathrm{ml})\end{array}$} \\
\hline
\end{tabular}

Sensitivity: Limit of detection (LOD) for Caspofungin was $0.001 \mu \mathrm{g} / \mathrm{mL}$ and limit of quantification (LOQ) for Caspofungin was $0.003 \mu \mathrm{g} / \mathrm{mL}$. The results of LOD and LOQ were indicating a high sensitivity of the method.
Robustness: The HPLC parameters were deliberately varied from normal procedural conditions including the mobile phase flow rate was $1.0 \mathrm{~mL} / \mathrm{min}$. This was changed by \pm 0.2 units to 0.8 and $1.2 \mathrm{~mL} / \mathrm{min}$. The effect of stationary phase was studied by the use of LC columns from different batches at $35^{\circ} \mathrm{C}$. Under these variations, all analytes were adequately resolved and elution orders remained unchanged. The testing solution maintained a signal-to-noise ratio over 10 in all varied conditions. The peak resolution was all larger than 1.5 under each variation. 
International Journal of Trend in Scientific Research and Development (IJTSRD) ISSN: 2456-6470

Table-5: Robustness study of Casporan ${ }^{\circledR}$ lyophilized product for intravenous (IV) infusion solution at $100 \%$ level $(5 \mu \mathrm{g} / \mathrm{mL})$ :

\begin{tabular}{|l|l|l|l|l|l|l|}
\hline \multirow{2}{*}{ Parameter } & \multicolumn{2}{|l|}{$\begin{array}{l}\text { Caspofungin in Flow } \\
\text { increase study }\end{array}$} & \multicolumn{2}{l}{$\begin{array}{l}\text { Caspofungin in Flow } \\
\text { decrease study }\end{array}$} & \multicolumn{2}{l|}{$\begin{array}{l}\text { Caspofungin in Variable } \\
\text { column Study }\end{array}$} \\
\cline { 2 - 7 } & Run time & Peak Area & Run time & Peak Area & Run time & Peak Area \\
\hline Injection-1 & 2.868 & 8444635 & 3.601 & 8497213 & 3.256 & 7840441 \\
\hline Injection-2 & 2.871 & 8438791 & 3.688 & 8457061 & 3.351 & 7985651 \\
\hline Injection-3 & 2.963 & 8478020 & 3.664 & 8453433 & 3.155 & 7806125 \\
\hline Mean & 2.901 & 8453815.3 & 3.651 & 8469236 & 3.254 & 7877406 \\
\hline \% RSD & 1.854 & 21164.53 & 1.234 & 24296.89 & 3.012 & 95300.50 \\
\hline Std. Dev & 0.054 & 0.250 & 0.045 & 0.287 & 0.098 & 1.210 \\
\hline
\end{tabular}

\section{Analysis of the fixed dose combination tablet:}

Casporan ${ }^{\circledR} 50 \mathrm{mg}$ is a white to off-white powder/cake for infusion in a vial with a red aluminum band and a plastic cap. Casporan $\AA$ is a sterile, lyophilized product for intravenous (IV) infusion that contains a semisynthetic lipopeptide (echinocandin) compound synthesized from a fermentation product of Glarea lozoyensis. Casporan $\AA 50 \mathrm{mg}$ also contains: $39 \mathrm{mg}$ sucrose, $26 \mathrm{mg}$ mannitol, glacial acetic acid, and sodium hydroxide. The contents of 5 vials are emptied and their average weight was calculated and they were then finely blended. An amount of the homogenous powder equivalent to $5 \mathrm{mg}$ was transferred into a $100 \mathrm{ml}$ volumetric flask, added $40 \mathrm{ml}$ of diluents (Acetonitrile and water in the ratio of $50: 50 \mathrm{v} / \mathrm{v}$ ), sonicated for $30 \mathrm{~min}$, diluted to $100 \mathrm{ml}$ with diluents. $50 \mathrm{ml}$ sample taken from this solution was centrifuged at $3000 \mathrm{rpm}$ for $15 \mathrm{~min}$. A 5-ml aliquot from supernatant was then decanted to another $50-\mathrm{ml}$ volumetric flask. Test solutions were then made up to volume with the diluent. The amount of caspofungin in standard mixtures or dosage forms were individually calculated using the related linear regression equations.

On the basis of above results, the proposed method was applied to the determination of antifungal agent capsofungin present in freeze dried product for IV infusion. Figure-3 shows representative chromatograms obtained from the analysis of Casporan ${ }^{\circledR}$ is a sterile, lyophilized product for intravenous (IV) infusion. The differences between the amount claimed and those assayed were very low and the R.S.D. values were within the acceptable range mentioned by pharmacopoeias. The mean percentage recoveries obtained after six repeated experiments were found between 97.53 and 100.98 (Table 6), indicating that the results are accurate and precise and there is no interference from the common excipients used in the pharmaceutical dosage forms.

Table-6: Assay results of Capsofungin in lyophilized product for intravenous (IV) infusion

\section{\begin{tabular}{l|l|l} 
Formulation & Label Claim (mg/powder) & Amount found in (mg/powder)
\end{tabular}}

$50 \mathrm{mg}$
$49.50 \mathrm{mg}$ 
International Journal of Trend in Scientific Research and Development (IJTSRD) ISSN: 2456-6470

\section{Typical Chromatogram of Casporan ${ }^{\circledR}$ is a sterile, lyophilized product for intravenous (IV) infusion}

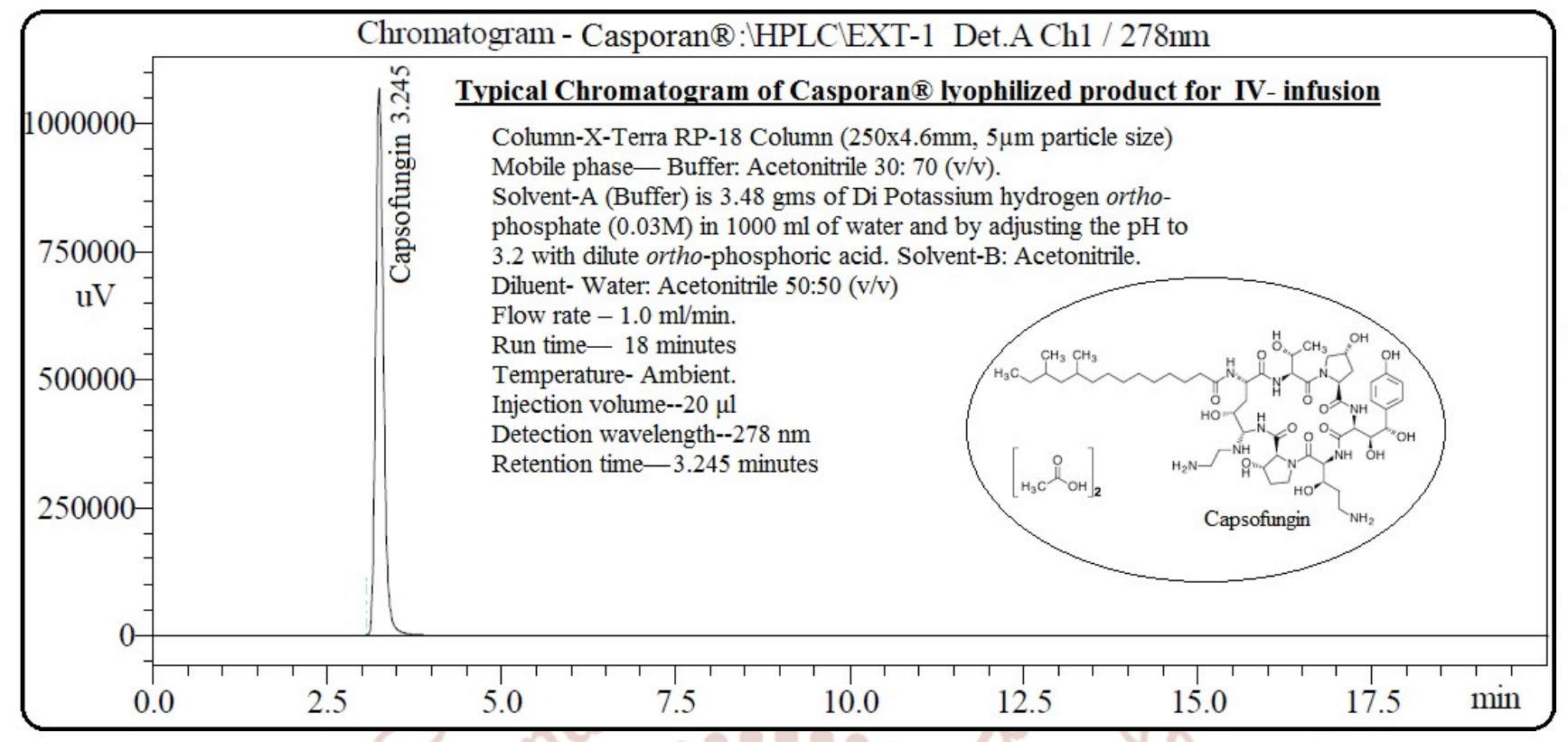

\section{CONCLUSION:}

In this study, a validated simple and reliable RPHPLC-PDA procedure was described for the assay of a CANCIDAS $\AA$ is a sterile, lyophilized product for intravenous (IV) infusion that contains a semisynthetic lipopeptide (echinocandin) for IV infusion, which is indicated is indicated as empirical therapy for presumed fungal infections in febrile, neutropenic adult and pediatric patients. To our present knowledge, no attempts have yet been made to estimate this freeze dried product by analytical procedure. The active pharmaceutical ingredient was successfully resolved and quantified using X-Terra RP-18 Octadecyl column $(250 \times 4.6 \mathrm{~mm}, 5 \mu \mathrm{m})$ in a relatively short run time of 18 minutes in isocratic mode $\mathrm{s}$ chromatographic method. The proposed method provides a good resolution between active ingredients. The developed method reported herein was validated by parameters as described in ICH-Q2B guideline. System suitability, specificity, linearity, LOD, LOQ values, within- and between-day precision and accuracy of the proposed technique were obtained during the validation studies. The proposed method has the advantages of simplicity, repeatability, sensitivity and requires less expensive reagents.

\section{REFERENCES:}

1. Freifeld AG, Bow EJ, Sepkowitz KA, Boeckh MJ, Ito JI, et al. (2011) Clinical practice guideline for the use of antimicrobial agents in neutropenic patients with cancer: 2010 update by the infectious diseases society of america. Clin Infect Dis 52: e56-93.

2. Bouffard FA, Zambias RA, Dropinski JF, Balkovec JM, Hammond ML, et al. (1994) Synthesis and antifungal activity of novel cationic pneumocandin B(o) derivatives. J Med Chem 37: 222-225.

3. Bartizal K, Gill CJ, Abruzzo GK, Flattery AM, Kong L, et al. (1997) In vitro preclinical evaluation studies with the echinocandin antifungal MK-0991 (L-743,872). Antimicrob Agents Chemother 41: 2326-2332.

4. Abruzzo GK, Flattery AM, Gill CJ, Kong L, Smith JG, et al. (1997) Evaluation of the echinocandin antifungal MK-0991 (L-743,872): efficacies in mouse models of disseminated aspergillosis, candidiasis, and cryptococcosis. Antimicrob Agents Chemother 41: 2333-2338.

5. Mora-Duarte J, Betts R, Rotstein C, Colombo AL, Thompson-Moya L, et al. (2002) Comparison of caspofungin and amphotericin B for invasive candidiasis. N Engl J Med 347: 2020-2029.

6. Maertens J, Raad I, Petrikkos G, Boogaerts M, Selleslag D, et al. (2004) Efficacy and safety of 
caspofungin for treatment of invasive aspergillosis in patients refractory to or intolerant of conventional antifungal therapy. Clin Infect Dis 39: $1563-1571$.

7. Walsh TJ, Teppler H, Donowitz GR, Maertens JA, Baden LR, et al. (2004) Caspofungin versus liposomal amphotericin B for empirical antifungal therapy in patients with persistent fever and neutropenia. N Engl J Med 351: 1391-1402.

8. Würthwein $\mathrm{G}$, Young $\mathrm{C}$, Lanvers-Kaminsky C, Hempel G, Trame MN, et al. (2012) Population pharmacokinetics of liposomal amphotericin B and caspofungin in allogeneic hematopoietic stem cell recipients. Antimicrob Agents Chemother 56: 536-543.

9. Hall RG 2nd, Swancutt MA, Meek C, Leff R, Gumbo T (2013) Weight drives caspofungin pharmacokinetic variability in overweight and obese people: fractal power signatures beyond two-thirds or three-fourths. Antimicrob Agents Chemother 57: 2259-2264.

10. van Wanrooy MJ, Santoe RN, van der Elst KC, Wilmer CM, van Hateren $\mathrm{K}$, Tret et al. (2013) Simultaneous quantification of anidulafungin and caspofungin in plasma by an accurate and simple liquid chromatography tandem mass-spectrometric method. There Drug Monit 35: 778-784.

11. Decosterd LA, Rochat B, Pesse B, Mercier T, Tissot F, et al. (2010) Multiplex ultra-performance liquid chromatography-tandem mass spectrometory method for simultaneous quantification in human plasma of fluconazole, itraconazole, hydroxyitraconazole, posaconazole, voriconazole, coriconazole-N-oxide, anidulafungin, and caspofungin. Antimicrob Agents Chemother 54: 5303-5315 